\title{
EVALUASI PENGANGGARAN BIDANG PENDIDIKAN DAN KESEHATAN DI KABUPATEN MADIUN
}

\author{
Tripitono Adi Prabowo \\ Prodi Ekonomi Pembangunan \\ Fakultas Ekonomi Universitas Trunojoyo Madura \\ e-mail: tripitono27@yahoo.com
}

\begin{abstract}
The purpose of this study was to analyze the budgeting education and health. It is based on program priorities of Madiun district and Law Number 23 of 2014 on Regional Government. This study using analysis of Value for Money Analysis and Budgeting Analysis Program. The conclusion of this study is the health sector budget in accordance with Law No. 23 in 2014, but the education budget is still below the target of $20 \%$ of the national budgeting. Furthermore, factors driving and inhibiting local budgeting is the human resource capacity planner uneven and insufficient coordination between SKPD .
\end{abstract}

Keywords : Education Budget, Budget of Health and local finances .

\section{PENDAHULUAN}

Undang-Undang Nomor 25 Tahun 2004 tentang Sistem Perencanaan Pembangunan Nasional (SPPN) merupakan pedoman bagi daerah dalam menyusun perencanaan pembangunan.Pada Pasal 1 dinyatakan bahwa Sistem Perencanaan Pembangunan Nasional adalah satu kesatuan tata cara perencanaan pembangunan untuk menghasilkan rencana-rencana pembangunan dalam jangka panjang, menengah dan tahunan yang dilaksanakan oleh unsur penyelenggara negara dan masyarakat di tingkat pusat dan daerah.

Salah satu dari hal tersebut implementasinya adalah Rencana Pembangunan Jangka Menengah Daerah (RPJMD) dimana dalam RPJMD tersebut memuat atau berisi rumusan mengenai visi, misi, dan Program Kepala Daerah yang kemudian dijabarkan ke dalam Strategi Pembangunan Daerah, Kebijakan Umum, Program Prioritas Kepala Daerah dan Arah Kebijakan Keuangan Daerah.

Pemerintah Kabupaten Madiun dalam mewujudkan Visi, Misi tersebut ada beberapa program prioritas yang menjadi sasaran pembangunan meliputi antara lain adalah bidang Pendidikan dan Kesehatan. Pembiayaan bidang Pendidikan mengacu pada Permendagri Nomor 37 Tahun 2014 tentang Pedoman Penyusunan Anggaran Pendapatan dan Belanja Daerah Tahun Anggaran 2015, harus mengalokasikan anggaran untuk fungsi pendidikan sekurang kurangnya 20 $\%$ dari Belanja Daerah, sedangkan untuk Bidang kesehatan mengalokasikan anggaran minimal $10 \%$ dari total belanja APBD di luar gaji, demikian juga untuk infrastruktur anggaran yang dialokasikan mininal $10 \%$ dari APBD.

Mengacu dari pelaksanaan kedua Undang-undang diatas, maka pemerintah daerah sebagai penyelenggaraan perencanaan, pelaksanaan dan evaluasi pembangunan daerah berkewajiban untuk mengimplementasikan amanah undang-undang tersebut secara komprehensif. Maksud dan tujuan dari penelitian ini adalah untuk menganalisis penganggaran program pembangunan 
strategis Kabupaten Madiun khususnya bidang pendidikan dan kesehatan.Selain itu juga mengidentifikasi faktor-faktor apa saja yang menjadi pendukung dan penghambat penganggaran program strategis Kabupaten Madiun.

\section{METODE PENELITIAN}

Metode penelitian ini menggunakan kuantif deskriptif, dimana teknik analisis data yang digunakan untuk menjawab permasalahan penganggaran program Bidang Pendidikan dan Kesehatan di kabupaten Madiun tahun 2013 dan 2014. Adapun teknik analisis yang dipergunakan adalah sebagai berikut.

\section{Value for Money Analysis}

Konsep value for money sangat penting bagi pemerintah sebagai pemberi pelayanan kepada masyarakat karena pemakaian konsep tersebut akan memberi manfaat berupa (Halim, 2012).

1. Efektivitas pelayanan publik, dalam arti pelayanan yang diberikan kepada masyarakat sesuai dengan apa yang telah direncanakan dan tepat sasaran.

2. Meningkatkan mutu pelayanan publik. Dengan menghilangkan setiap inefisiensi dalam seluruh tindakan pemerintah maka biaya pelayanan yang diberikan menjadi murah dan selalu dilakukan penghematan dalam pemakaian sumber daya.

3. Alokasi belanja yang lebih berorientasi pada kepentingan publik.

4. Meningkatkan publik cost awareness sebagai akar dari akuntabilitas publik.

\section{Budgeting Program Analysis}

Teknik analisis ini digunakan untuk mengetahui program-program yang dijadikan prioritas pemerintah daerah sesuai urutan berdasarkan indikator pencapaian visi misi kepala daerah dan program prioritas arahan pemerintah pusat. Melalui teknik ini diketahui bagaimana program pendidikan dan kesehatan berkontribusi terhadap tujuan pembangunan kabupaten Madiun beserta kesesuaian penganggarannya. Analisa akan dilakukan melalui tiga tahap sebagai berikut.

a. Tahap Pertama. Pada tahap ini akan dianalisis program-program berdasarkan kriteria pencapaian output visi misi pemerintah daerah. Pada matrik prioritas ini akan dihasilkan pengurutan prioritas program sesuai dengan total hasil penjumlahan mulai dari nilai tertinggi hingga terendah. Selajutnya akan dipilih program-program dengan nilai total di atas ratarata jumlah total.

b. Tahap Kedua. Pada tahap selanjutnya, akan dianalisa kembali urutan program-program yang memiliki nilai di atas rata-rata sebagaimana dihasilkan pada tahap pertama. Analisa tahap kedua ini merupakan penentuan prioritas utama program yang akan menghasilkan urutan program terpenting dari program yang terpilih.

c. Tahap Ketiga. Sedangkan tahap ketiga ini akan dibandingkan secara bersama, bagaimana setiap program yang terpilih dari peroses pertama dan kedua di atas memiliki kesesuaian. Kesesuaian sebagaimana dimaksud adalah perbandingan antara urutan kebijakan alokasi anggaran setiap program dengan urutan prioritas program berdasarkan pencapaian visi misi kepala daerah (RPJMD). 
Kriteria yang digunakan untuk memberi bobot pada program SKPD bidang pendidikan dan kesehatan adalah sebagai berikut;

1. Bidang Kesehatan :

Kriteria :

a. Meningkatkan derajat kesehatan masyarakat

b. Efisiensi biaya

c. Efektivitas pencapaian visi misi kepala daerah.

2. Bidang Pendidikan :

Kriteria :

a. Meningkatnya kecerdasan masyarakat

b. Meningkatnya IPM

c. Berkurangnya angka putus sekolah

d. Meningkatnya minat baca masyarakat

\section{HASIL PENELITIAN}

Gambaran mengenai Program Prioritas kabupaten Madiun, dapat diketahui dari dokumen RPJMD kabupaten Madiun Tahun 2013-2018. Pembiayaan program-program prioritas di Kabupaten Madiun tentu harus disesuaikan dengan Kapasitas Riil Kemampuan Keuangan Daerah yang secara lebih detil selanjutnya penggunaannya dilakukan melalui pendekatan 3 (tiga) prioritas, yaitu:

1. Prioritas Pertama, dialokasikan untuk pembangunan yang langsung mencapai visi misi kepala daerah;

2. Prioritas Kedua, dialokasikan untuk pembangunan yang terkait dengan urusan wajib dan pilihan sebagai pendukung visi misi kepala daerah;

3. Prioritas Ketiga, digunakan untuk alokasi belanja tidak langsung seperti bantuan sosial, hibah, belanja keuangan desa, belanja tidak terduga, belanja subsidi dan belanja bantuan keuangan kepada propinsi / kabupaten / kota dan pemerintah desa.

Berpijak dari penjabaran Visi, Misi, Tujuan dan Sasaran sebagaimana ditunagkan dalam RPJMD, maka rumusan kebijakan mengenai program strategis yang perlu mendapatkan perhatian khusus, yaitu meliputi beberapa bidang; 1) Kesehatan, 2) Pendidikan, 3) Pertanian, 4) Ketenagakerjaan, 5) Lingkungan Hidupdan 6) Infrastruktur.

\section{Alokasi Belanja Langsung SKPD}

Alokasi Belanja Langsung pada tiap SKPD merupakan salah satu cermin komitmen dan good will Pemerintah daerah dalam implementasi kebijakan keuangan Daerah. Secara umum memang besarnya alokasi anggaran bukan merupakan indicator bahwa SKPD terkait memiliki program prioritas daerah. Akan tetapi hal ini dapat memberikan petunjuk mengenai SKPD mana saja yang memiliki tanggungjawab besar untuk mengalokasikan BL tersebut.

Tabel 1

Belanja Langsung Beberapa SKPD Kabupaten Madiun Tahun 2013 dan 2014

\begin{tabular}{clcr}
\hline No & \multicolumn{1}{c}{ SKPD } & Jumlah (Rp.) & $(\%)$ \\
\hline 1 & Dinas Pendidikan & $72,783,940,000.00$ & 21.18 \\
2 & Dinas Kesehatan & $12,781,125,330.00$ & 3.72 \\
3 & Rumah Sakit Umum Daerah & $29,440,659,500.00$ & 8.57 \\
\hline
\end{tabular}




\begin{tabular}{clrr}
\hline 4 & Rumah Sakit Umum Daerah Dolopo & $3,650,000,000.00$ & 1.06 \\
5 & Dinas PU Bina Marga dan Cipta Karya & $98,361,114,600.00$ & 28.63 \\
6 & Dinas PU Pengairan & $21,940,242,770.00$ & 6.39 \\
7 & Dinas Kebersihan dan Pertamanan & $10,179,378,000.00$ & 2.96 \\
8 & Dinas Koperasi, Perindustrian, & $4,514,331,000.00$ & \\
9 & Perdagangan dan Pariwisata & $7,075,327,619.00$ & 1.31 \\
9 & Bagian Umum & $5,527,488,806.00$ & 1.61 \\
10 & Dinas Pendapatan & $9,103,272,630.00$ & \\
11 & Dinas Pertanian Tanaman Pangan dan & & 2.65 \\
12 & Dortikultura & $7,873,933,480.00$ & 2.29 \\
\hline
\end{tabular}

Sumber : Bappeda Kab. Madiun, 2015

Berdasarkan data tabel di atas, diketahui bahwa Dinas PU Bina Marga dan Cipta Karya memiliki alokasi anggaran yang paling tinggi, yaitu Rp.98,361,114,600.00 atau 28,63\% dari total BL. Pada posisi kedua adalah Dinas Pendidikan dengan alokasi anggaran Belanja Langsung sebesar Rp. $72,783,940,000.00$ atau $21,18 \%$. Sedangkan posisi ketiga dan seterusnya ditempati oleh SKPD di bidang kesehatan, yaitu RSUD kabupaten Madiun Rp.29.440.659.500 (8,57\%), Dinas Kesehatan Rp.12.781.125.330 (3,72\%) dan RSUD Dolopo sebesar Rp.3.650.000.000,00 (1,06\%). Selain itu, bidang infrastruktur lain yaitu Dinas PU Pengairan mendapatkan alokasi sebesar Rp.21.940.242.770,00 atau 6,39\%. Berdasarkan proporsi ini, dapat diambil sebuah kongklusi umum bahwa alokasi Belanja Langsung dengan proporsi besar adalah Bidang Pendidikan, Bidang Insfrastruktur dan Bidang Kesehatan. Ketiga bidang ini sesuai dengan Visi RPJMD kabupaten Madiun tahun 2013-2018 dan UU No. 23 tahun 2014 tentang pemerintah daerah.

\section{Analisa Pembiayaan Bidang.}

\section{Bidang Kesehatan}

Berikut disajikan alokasi anggaran beserta proporsinya pada bidang Kesehatan. Data meliputi realisasi anggaran tahun 2013 dan tahun 2014. Bidang kesehatan ini termasuk pembiayaan Urusan Wajib yang diselenggarakan oleh Dinas Kesehatan kabupaten Madiun, RSUD Caruban dan RSUD Dolopo. Berikut akan disajikan data pembiayaan bidang kesehatan Tahun 2013.

Tabel 2

Pembiayaan Urusan Wajib Dinas Kesehatan Tahun 2013

\begin{tabular}{|c|c|c|}
\hline URAIAN & ANGGARAN & PORSI \\
\hline Program Pelayanan Administrasi Perkantoran & $653.834 .850,00$ & $2,62 \%$ \\
\hline $\begin{array}{l}\text { Program Peningkatan Sarana Dan Prasarana } \\
\text { Aparatur }\end{array}$ & $403.229 .600,00$ & $1,62 \%$ \\
\hline $\begin{array}{l}\text { Program Peningkatan Kapasitas Sumber Daya } \\
\text { Aparatur }\end{array}$ & $333.050 .000,00$ & $1,34 \%$ \\
\hline $\begin{array}{l}\text { Program Peningkatan Pengembangan Sistem } \\
\text { Pelaporan Capaian Kinerja Dan Keuangan }\end{array}$ & $355.113 .700,00$ & $1,42 \%$ \\
\hline Program Obat Dan Perbekalan Kesehatan & $611.821 .420,00$ & $2,45 \%$ \\
\hline
\end{tabular}


Program Upaya Kesehatan Masyarakat

Program Pengawasan Obat Dan Makanan

Program Promosi Kesehatan Dan

Pemberdayaan Masyarakat

Program Perbaikan Gizi Masyarakat

Program Pengembangan Lingkungan Sehat

Program Pencegahan Dan Penanggulangan

Penyakit Menular

Program Standarisasi Pelayanan Kesehatan

Program Pelayanan Kesehatan Penduduk Miskin

Program Peningkatan Pelayanan Publik

\begin{tabular}{rr}
$9.802 .315 .951,00$ & $39,31 \%$ \\
$84.000 .000,00$ & $0,34 \%$ \\
$534.515 .000,00$ & $2,14 \%$ \\
$600.708 .000,00$ & $2,41 \%$ \\
$173.477 .500,00$ & $0,70 \%$ \\
$703.571 .000,00$ & $2,82 \%$ \\
$119.652 .500,00$ & $0,48 \%$ \\
$7.097 .250 .000,00$ & $28,47 \%$ \\
$3.460 .289 .520,00$ & $13,88 \%$ \\
$24.932 .829 .041,00$ & $100 \%$ \\
\hline
\end{tabular}

JUMLAH

Pada tahun 2013 porsi anggaran terbesar yang dibiayai oleh Dinas Kesehatan adalah program upaya kesehatan masyarakat dengan prosentase sebesar $39 \%$ dari keseluruhan anggaran pembiayaan. Kemudian peringkat kedua adalah Program Kesehatan Penduduk Miskin sebesar 28,47\%, dan peringkat ketiga adalah Program Peningkatan Pelayanan Publik sebesar 13,88\%. Sedangkan alokasi terendah dari anggaran Dinas Kesehatan digunakan untuk program pengawasan obat dan makanan.

Tabel 3

Pembiayaan Urusan Wajib Dinas Kesehatan Tahun 2014

\begin{tabular}{|c|c|c|}
\hline URAIAN & ANGGARAN & PORSI \\
\hline \multirow{2}{*}{$\begin{array}{l}\text { Program Pelayanan Administrasi Perkartoran } \\
\text { Program Peningkatan Sarana Dan Prasarana } \\
\text { Aparatur }\end{array}$} & $785.155 .600,00$ & $1,37 \%$ \\
\hline & $842.283 .800,00$ & $1,47 \%$ \\
\hline $\begin{array}{l}\text { Program Peningkatan Kapasitas Sumber Daya } \\
\text { Aparatur }\end{array}$ & $5.000 .000,00$ & $0,01 \%$ \\
\hline $\begin{array}{l}\text { Program Peningkatan Pengembangan Sistem } \\
\text { Pelaporan Capaian Kinerja Dan Keuangan }\end{array}$ & $369.619 .000,00$ & $0,64 \%$ \\
\hline Program Obat Dan Perbekalan Kesehatan & $2.534 .884 .800,00$ & $4,41 \%$ \\
\hline Program Upaya Kesehatan Masyarakat & $12.097 .275 .850,00$ & $21,06 \%$ \\
\hline \multirow{2}{*}{$\begin{array}{l}\text { Program Pengawasan Obat Dan Makanan } \\
\text { Program Promosi Kesehatan Dan } \\
\text { Pemberdayaan Masyarakat }\end{array}$} & 107.688.600,00 & $0,19 \%$ \\
\hline & $334.315 .000,00$ & $0,58 \%$ \\
\hline Program Perbaikan Gizi Masyarakat & $638.769 .400,00$ & $1,11 \%$ \\
\hline \multirow{2}{*}{$\begin{array}{l}\text { Program Pengembangan Lingkungan Sehat } \\
\text { Program Pencegahan Dan Penanggulangan } \\
\text { Penyakit Menular }\end{array}$} & $262.095 .000,00$ & $0,46 \%$ \\
\hline & $695.766 .200,00$ & $1,21 \%$ \\
\hline \multirow{2}{*}{$\begin{array}{l}\text { Program Standarisasi Pelayanan Kesehatan } \\
\text { Program Pelayanan Kesehatan Penduduk } \\
\text { Miskin }\end{array}$} & $88.360 .000,00$ & $0,15 \%$ \\
\hline & $17.159 .505 .906,00$ & $29,87 \%$ \\
\hline Program Pengadaan, Peningkatan Dan & $520.000 .000,00$ & $0,91 \%$ \\
\hline
\end{tabular}


Perbaikan Sarana Dan Prasarana

Puskesmas/Puskesmas Pembantu Dan J

Program Peningkatan Pelayanan Publik

Program Pelayanan Kesehatan Peserta

Jaminan Kesehatan Nasional

$10.274 .898 .300,00 \quad 17,89 \%$

$10.728 .445 .000,00 \quad 18,68 \%$

JUMLAH $\quad 57.444 .062 .456,00 \quad 100 \%$

Pada Dinas Kesehatan porsi anggaran terbesar pada tahun 2014 dialokasikan untuk pembiayaan program pelayanan kesehatan penduduk miskin, yaitu sebesar $29,87 \%$ dari total keseluruhan anggaran yang dimiliki. Sedangkan alokasi anggaran terendah digunakan untuk program peningkatan kapasitas sumber daya aparatur yaitu sebesar $0,01 \%$ dari anggaran pembiayaan. Pada tahun 2014 ada perbedaan alokasi anggaran. Hal ini berimbas pada menurunnya porsi alokasi pembiayaan untuk program upaya kesehatan masyarakat. Pada tahun 2014 program upaya kesehatan masyarakat menempati prioritas kedua (sesuai dengan besaran anggaran) yaitu sebesar 21,06\%. Namun demikian besaran nominal anggaran tetap mengalami peningkatan.

Tabel 4

Pembiayaan Urusan Wajib Kesehatan RSUD Caruban Tahun 2013

\begin{tabular}{lrr}
\hline \multicolumn{1}{c}{ URAIAN } & \multicolumn{1}{c}{ ANGGARAN } & \multicolumn{1}{c}{ PORSI } \\
\hline $\begin{array}{l}\text { Program Pelayanan Administrasi } \\
\text { Perkantoran }\end{array}$ & $1.680 .956 .400,00$ & $4,19 \%$ \\
$\begin{array}{l}\text { Program Peningkatan Sarana Dan } \\
\text { Prasarana Aparatur }\end{array}$ & $499.000 .000,00$ & $1,24 \%$ \\
$\begin{array}{l}\text { Program Peningkatan Kapasitas Sumber } \\
\text { Daya Aparatur }\end{array}$ & $326.000 .000,00$ & $0,81 \%$ \\
$\begin{array}{l}\text { Program Peningkatan Pengembangan } \\
\text { Sistem Pelaporan Capaian Kinerja Dan }\end{array}$ & $537.690 .000,00$ & $1,34 \%$ \\
$\begin{array}{l}\text { Keuangan } \\
\text { Program Promosi Kesehatan Dan }\end{array}$ & & \\
$\begin{array}{l}\text { Pemberdayaan Masyarakat } \\
\text { Program Standarisasi Pelayanan Kesehatan }\end{array}$ & $303.100 .000,00$ & $0,75 \%$ \\
$\begin{array}{l}\text { Program Pelayanan Kesehatan Penduduk } \\
\text { Miskin }\end{array}$ & $34.850 .000,00$ & $0,09 \%$ \\
$\begin{array}{l}\text { Program Pengadaan, Peningkatan Sarana } \\
\text { \& Prasarana Rumah Sakit/ Rumah Sakit }\end{array}$ & $23.101 .631 .665,00$ & $57,52 \%$ \\
Jiwa/Rumah Sakit Paru Paru & & \\
$\begin{array}{l}\text { Program Pemeliharaansarana \& Prasarana } \\
\text { Rumah Sakit/ Rumah Sakit Jiwa/Rumah }\end{array}$ & $741.500 .000,00$ & $1,85 \%$ \\
$\begin{array}{l}\text { Sakit Paru Paru } \\
\text { Program Peningkatan Pelayanan Publik }\end{array} \quad 12.850 .360 .000,00$ \\
$\quad$ JUMLAH & $40.160 .088 .065,00$ & $32,00 \%$ \\
\hline
\end{tabular}

Urusan wajib kesehatan yang dilaksanakan oleh RSUD Caruban pada tahun 2013 telah membiayai 10 program kesehatan. Pembiayaan terbesar dipergunakan untuk program pengadaan, peningkatan sarana dan prasarana rumah sakit/rumah sakit jiwa/rumah sakit paru-paru yaitu sebesar $57,52 \%$. Sedangkan alokasi terendah adalah untuk pembiayaan program pelayanan 
kesehatan untuk penduduk miskin yaitu sebesar 0,09\% atau Rp 34.850.000,--

Tabel 5

Pembiayaan Urusan Wajib Kesehatan oleh RSUD Caruban Tahun 2014

\begin{tabular}{|c|c|c|}
\hline URAIAN & ANGGARAN & PORSI \\
\hline Program Pelayanan Administrasi Perkartoran & $1.736 .820 .000,00$ & $3,52 \%$ \\
\hline $\begin{array}{l}\text { Program Peningkatan Sarana Dan Prasarana } \\
\text { Aparatur }\end{array}$ & $614.000 .000,00$ & $1,25 \%$ \\
\hline $\begin{array}{l}\text { Program Peningkatan Kapasitas Sumber } \\
\text { Daya Aparatur }\end{array}$ & $704.250 .000,00$ & $1,43 \%$ \\
\hline $\begin{array}{l}\text { Program Peningkatan Pengebangan Sistem } \\
\text { Pelaporan Capaian Kinerja Dan Keuangan }\end{array}$ & $511.900 .000,00$ & $1,04 \%$ \\
\hline $\begin{array}{l}\text { Program Promosi Kesehatan Dan } \\
\text { Pemberdayaan Masyarakat }\end{array}$ & $69.000 .000,00$ & $0,14 \%$ \\
\hline Program Standarisasi Pelayanan Kesehatan & $438.600 .000,00$ & $0,89 \%$ \\
\hline $\begin{array}{l}\text { Program Pelayanan Kesehatan Penduduk } \\
\text { Miskin }\end{array}$ & $42.520 .000,00$ & $0,09 \%$ \\
\hline $\begin{array}{l}\text { Program Pengadaan, Peningkatan Sarana \& } \\
\text { Prasarana Rumah Sakit / Rumah Sakit Jiwa / } \\
\text { Rumah Sakit Paru-Paru } \\
\text { Program Pemeliharaan Sarana \& Prasarana }\end{array}$ & $27.163 .575 .906,70$ & $55,12 \%$ \\
\hline $\begin{array}{l}\text { Rumah Sakit / Rumah Sakit Jiwa / Rumah } \\
\text { Sakit Paru-Paru }\end{array}$ & $783.000 .000,00$ & $1,59 \%$ \\
\hline $\begin{array}{l}\text { Program Kemitraan Peningkatan Pelayanan } \\
\text { Kesehatan }\end{array}$ & $40.000 .000,00$ & $0,08 \%$ \\
\hline Program Peningkatan Pelayanan Publik & $17.175 .588 .382,81$ & $34,85 \%$ \\
\hline JUMLAH & $49.279 .254 .289,51$ & $100 \%$ \\
\hline
\end{tabular}

Pada tahun 2014 program pelayan terhadap penduduk miskin tidak mengalami perubahan porsi, yaitu tetap pada bagian $0,09 \%$ dari total keseluruhan anggaran pembiayaan. Secara nominal meningkat sebanyak 7.670.000,- (dari Rp 34.850.000,- menjadi Rp 42.520.000,-). Nominal tersebut tetap berada pada urutan terbawah dengan kata lain mendapat prioritas paling terakhir. Sedangkan prioritas utama yang dibiayai oleh RSUD Caruban masih pada program pengadaan, peningkatan sarana \& prasarana rumah sakit/rumah sakit jiwa/rumah sakit paru paru yaitu sebesar $55,12 \%$.

Tabel 6

Pembiayaan Wajib Kesehatan oleh RSUD Dolopo Tahun 2013

\begin{tabular}{lrr}
\multicolumn{1}{c}{ URAIAN } & \multicolumn{1}{c}{ ANGGARAN } & PORSI \\
\hline Program Pelayanan Administrasi Perkantoran & $910.491 .600,00$ & $6,11 \%$ \\
Program Peningkatan Sarana Dan Prasarana & $144.000 .000,00$ & $0,97 \%$ \\
Aparatur & $63.000 .000,00$ & $0,42 \%$ \\
Program Peningkatan Disiplin Aparatur & $127.000 .000,00$ & $0,85 \%$ \\
Program Peningkatan Kapasitas Sumber Daya & & \\
Aparatur &
\end{tabular}


Program Peningkatan Pengembangan Sistem Pelaporan Capaian Kinerja Dan Keuangan

Program Obat Dan Pembekalan Kesehatan

Program Upaya Kesehatan Masyarakat

Program Promosi Kesehatan Dan

Pemberdayaan Masyarakat

Program Standarisasi Pelayanan Kesehatan

Program Pelayanan Penduduk Miskin

Program Pengadaan, Peningkatan Sarana \&

Prasarana Rumah Sakit/Rumah Sakit

Jiwa/Rumah Sakit Paru Paru

Program Pemeliharaan Sarana Dan Prasarana

Rumah Sakit Jiwa/Rumah Sakit Paru-Paru

Program Kemitraan Peningkatan Pelayanan

Kesehatan

Program Peningkatan Pelayanan Publik

Program Penataan Penguasaan, Pemilikan,

Penggunaan Dan Pemanfaatan Tanah

$$
\begin{array}{rr}
711.500 .000,00 & 4,78 \% \\
500.000 .000,00 & 3,36 \% \\
4.200 .000 .000,00 & 28,20 \% \\
32.100 .000,00 & 0,22 \% \\
43.855 .000,00 & 0,29 \% \\
750.000 .000,00 & 5,04 \% \\
\hline 2.318 .840 .400,00 & 15,57 \% \\
& \\
302.500 .000,00 & 2,03 \% \\
\hline 2.231 .200 .000,00 & 14,98 \% \\
1.057 .500 .000,00 & 7,10 \% \\
1.500 .000 .000,00 & 10,07 \%
\end{array}
$$

\begin{tabular}{|c|c|c|}
\hline URAIAN & ANGGARAN & PORSI \\
\hline \multirow{2}{*}{$\begin{array}{l}\text { Program Pelayanan Administrasi Perkantoran } \\
\text { Program Peningkatan Sarana Dan Prasana } \\
\text { Aparatur }\end{array}$} & $1.011 .504 .255,00$ & $5,60 \%$ \\
\hline & $201.740 .000,00$ & $1,12 \%$ \\
\hline \multirow{2}{*}{$\begin{array}{l}\text { Program Peningkatan Disiplin Aparatur } \\
\text { Program Peningkatan Kapasitas Sumber Daya } \\
\text { Aparatur }\end{array}$} & $77.750 .000,00$ & $0,43 \%$ \\
\hline & $166.875 .000,00$ & $0,92 \%$ \\
\hline $\begin{array}{l}\text { Program Peningakatan Pegembangan Sistem } \\
\text { Pelaporan Capaian Kinerja Dan Keuangan }\end{array}$ & $796.250 .000,00$ & $4,41 \%$ \\
\hline $\begin{array}{l}\text { Program Promosi Kesehatan Dan } \\
\text { Pemberdayaan Masyarakat }\end{array}$ & $25.000 .000,00$ & $0,14 \%$ \\
\hline $\begin{array}{l}\text { Program Pelayanan Penduduk Miskin } \\
\text { Program Pengadaan, Peningkatan Sarana \& }\end{array}$ & $85.850 .000,00$ & $0,48 \%$ \\
\hline $\begin{array}{l}\text { Prasarana Rumah Sakit / Rumah Sakit Jiwa / } \\
\text { Rumah Sakit Paru-Paru } \\
\text { Program Pemeliharaan Sarana \& Prasarana }\end{array}$ & 10.622.280.170,00 & $58,86 \%$ \\
\hline $\begin{array}{l}\text { Rumah Sakit / Rumah Sakit Jiwa / Rumah } \\
\text { Sakit Paru-Paru }\end{array}$ & $401.459 .700,00$ & $2,22 \%$ \\
\hline $\begin{array}{l}\text { Program Kemitraan Peningkatan Pelayanan } \\
\text { Kesehatan }\end{array}$ & $15.000 .000,00$ & $0,08 \%$ \\
\hline Program Peningkatan Pelayanan Publik & $4.644 .000 .000,00$ & $25,73 \%$ \\
\hline JUMLAH & 18.047.709.125,00 & $100 \%$ \\
\hline
\end{tabular}

JUMLAH $\quad 14.891 .987 .000,00 \quad 100 \%$

Pembiayaan Wajib Kesehatan oleh RSUD Dolopo Tahun 2014 
Alokasi pembiayaan urusan wajib kesehatan yang ditangani oleh RSUD Dolopo pada tahun 2013 dan tahun 2014 terdapat perbedaan yang cukup signifikan. Perbedaan yang sangat terlihat adalah alokasi pembiayaan untuk program pengadaan, peningkatan sarana dan prasarana rumah sakit/rumah sakit jiwa/rumah sakit paru paru. Pada tahun 2013 alokasi anggaran yang digunakan untuk membiayai program tersebut adalah sebesar $15,57 \%$ dengan nominal Rp 2.318.840.400,-- dan pada tahun 2014 meningkat menjadi 58,86\% dengan nominal sebesar Rp 10.622.280.170,-. Program kedua yang mengalami perubahan alokasi cukup signifikan adalah program upaya kesehatan masyarakat. Pada tahun 2013 prosentase pembiayaan adalah sebesar $28,20 \%$ dengan nominal 4.200.000.000,- sedangkan pada tahun 2014 pembiayaan pada program ditiadakan. Demikian juga program yang sebelumnya ada di tahun 2013 yaitu program penataan penguasaan, pemilikan, penggunaan dan pemanfaatan tanah, pada tahun 2014 program tersebut sudah dihapus.

\section{Bidang Pendidikan}

Bentuk keseriusan pemerintah dalam bidang pendidikan tertuang dalam Pasal 31 ayat 4 UUD 1945 Amandemen ke 4 mengamanatkan bahwa negara memprioritaskan anggaran pendidikan sekurang-kurangnya 20 persen dari APBN serta dari APBD untuk memenuhi kebutuhan penyelenggaraan pendidikan nasional. Hal ini dikuatkan dengan putusan Mahkamah Konstitusi Nomor: 013/PUU-VI/2008, Pemerintah harus menyediakan anggaran pendidikan sekurang-kurangnya 20 persen dari APBN dan APBD untuk memenuhi kebutuhan penyelenggaraan pendidikan nasional. Alokasi anggaran diharapkan dapat memenuhi kebutuhan yang terkait dengan peningkatan kualitas pendidikan. Alokasi anggaran pendidikan lebih spesifik dituangkan dalam pasal 49 UU Nomor 20 tahun 2003 pasal 1 yaitu Dana pendidikan selain gaji pendidik dan biaya pendidikan kedinasan dialokasikan minimal $20 \%$ dari Anggaran Pendapatan dan Belanja Negara (APBN) pada sektor pendidikan dan minimal $20 \%$ dari Anggaran Pendapatan dan Belanja Daerah (APBD).

Alokasi pembiayaan Bidang Pendidikan Kabupaten Madiun ditangani oleh Dinas Pendidikan. Dimana di dalam pembiayaan program-program urusan wajib pendidikan prosentase terbesar (2013) dialokasikan untuk program wajib belajar sembilan tahun yaitu sebesar $65,28 \%$ dengan nominal Rp 43.000.975.235,- dari total anggaran yang dikelola oleh Dinas Pendidikan. Sedangkan alokasi terendah digunakan untuk pembiayaan program pendidikan luar biasa, yaitu $0,02 \%$ atau sebesar 10.000.000,-

Tabel 8

Pembiayaan Wajib Pendidikan oleh Dinas Pendidikan Tahun 2013

\begin{tabular}{lrr}
\hline \multicolumn{1}{c}{ URAIAN } & ANGGARAN & PORSI \\
\hline Program Pelayanan Administrasi Perkantoran & $495.800 .000,00$ & $0,75 \%$ \\
$\begin{array}{l}\text { Program Peningkatan Sarana Dan } \\
\text { Prasarana Apartr }\end{array}$ & $133.000 .000,00$ & $0,20 \%$ \\
Program Peningkatan Pengembangan Sistem & $538.362 .000,00$ & $0,82 \%$ \\
Pelaporan Capaian Kinerja Dan Keuangan & & \\
Program Pendidikan Anak Usia Dini & $1.720 .800 .000,00$ & $2,62 \%$ \\
Program Wajib Belajar Pendidikan Dasar 9 & $43.000 .975 .235,00$ & $65,38 \%$ \\
Tahun & &
\end{tabular}


Program Pendidikan Menengah

Program Pendidikan Non Formal

Program Pendidikan Luar Biasa

Program Peningkatan Mutu Pendidikan Dan

Tenaga Kependidikan

Program Manajemen Pelayanan Pendidikan

Program Pengembangan Nilai Budaya $\begin{array}{rr}15.675 .390 .000,00 & 23,83 \% \\ 385.000 .000,00 & 0,59 \% \\ 10.000 .000,00 & 0,02 \% \\ 595.000 .000,00 & 0,90 \%\end{array}$

$2.495 .542 .500,00 \quad 3,79 \%$

$725.000 .000,00 \quad 1,10 \%$

$65.774 .869 .735,00 \quad 100 \%$

Tabel 9

Pembiayaan Wajib Pendidikan oleh Dinas Pendidikan Tahun 2014

\begin{tabular}{lrr}
\multicolumn{1}{c}{ URAIAN } & \multicolumn{1}{c}{ ANGGARAN } & PORSI \\
& & \\
\hline Program Pelayanan Administrasi Perkartoran & $583.636 .150,00$ & $1,11 \%$ \\
Program Peningkatan Sarana Dan Prasarana & $237.000 .000,00$ & $0,45 \%$ \\
Aparatur & $30.000 .000,00$ & $0,06 \%$ \\
Program Peningkatan Disiplin Aparatur & & \\
Program Peningkatan Pengembangan Sistem & $543.871 .000,00$ & $1,03 \%$ \\
Pelaporan Capaian Kinerja Dan Keuangan & $2.650 .190 .000,00$ & $5,03 \%$ \\
Program Pendidikan Anak Usia Dini & & \\
Program Wajib Belajar Pendidikan Dasar & $33.655 .382 .202,00$ & $63,93 \%$ \\
Sembilan Tahun & $8.604 .558 .950,00$ & $16,35 \%$ \\
Program Pendidikan Menengah & $1.945 .072 .500,00$ & $3,69 \%$ \\
Program Pendidikan Non Formal & $20.500 .000,00$ & $0,04 \%$ \\
Program Pendidikan Luar Biasa & & \\
Program Peningkatan Mutu Pendidik Dan & $1.314 .107 .500,00$ & $2,50 \%$ \\
Tenaga Kependidikan & $1.716 .512 .618,00$ & $3,26 \%$ \\
Program Manajemen Pelayanan Pendidikan & $1.340 .550 .000,00$ & $2,55 \%$ \\
Program Pengembangan Nilai Budaya & $52.641 .380 .920,00$ & $100 \%$ \\
\hline$\quad$ JUMLAH & & \\
\hline
\end{tabular}

Pada tahun 2014 porsi terbesar anggaran tetap digunakan untuk membiayai program wajib belajar sembilan tahun dengan prosentasi sebesar $63,93 \%$ turun $1,45 \%$ dari tahun sebelumnya (2013). Dengan nominal yang jauh lebih kecil dari tahun sebelumnya, yaitu sebesar 33.655.382.202,-. Angka tersebut berkurang jauh mencapai 9.345.693.033,-. Sedangkan alokasi terkecil tetap pada program pendidikan luar biasa yakni sebesar $0,04 \%$.

\section{Analisa Penganggaran Bidang Pendidikan dan Kesehatan.}

Analisis penganggaran Bidang Pendidikan dan Kesehatan kabupaten Madiun tahun 2013 dan tahun 2014untuk mengidentifikasi program strategis yang sesuai dengan RPJMD Kab. Madiun serta kesesuaian anggarannya menggunakan beberapa kriteria sebagai berikut;

a. Dampak langsung pada peningkatan pendidikan atau kesehatan masyarakat.

b. Jangka waktu tercapainya dampak 
c. Efisiensi biaya

d. Kesesuaian dengan visi misi kepala daerah

e. Kesesuaian dengan amanat Permendagri 37 Tahun 2012 (Penyusunan APBD 2013) dan Permendagri 27 tahun 2013 (Penyusunan APBD 2014)

Analisa penganggaran program-program strategis selanjutnya akan membandingkan antara kebijakan alokasi anggaran di tiap Bidang/SKPD dengan urutan berdasarkan kriteria di atas. Dengan demikian akan diketahui bahwa tidak setiap program yang memiliki alokasi anggaran yang besar itu merupakan program prioritas.

\section{Bidang Kesehatan.}

Berikut ini akan disampaikan ilustrasi kebijakan alokasi anggaran Dinas Kesehatan dengan mengelaborasi antara analisis kebijakan alokasi anggaran dengan identifikasi program strategis.

Tabel 10

\section{Analisa Program Strategis Dinas Kesehatan}

\begin{tabular}{|c|c|c|c|c|}
\hline \multicolumn{2}{|c|}{ Dinas/kantor/ Unit } & Proporsi Anggaran 2013 & \multicolumn{2}{|c|}{ Proporsi Anggaran 2014} \\
\hline \multicolumn{2}{|c|}{ Dinas Kesehatan } & $7.65 \%$ & \multicolumn{2}{|c|}{$13.82 \%$} \\
\hline \multicolumn{2}{|c|}{ RSUD Caruban } & $12.33 \%$ & \multicolumn{2}{|c|}{$11.85 \%$} \\
\hline \multicolumn{2}{|c|}{ RSUD Dolopo } & $4.57 \%$ & \multicolumn{2}{|c|}{$4.34 \%$} \\
\hline & TOTAL & $24.55 \%$ & \multicolumn{2}{|c|}{$30.00 \%$} \\
\hline No. & \multicolumn{2}{|c|}{ Program } & $\begin{array}{c}\text { Prosentase } \\
\text { Anggaran } \\
\text { Program di } \\
\text { SKPD }\end{array}$ & $\begin{array}{c}\text { Ranking } \\
\text { Program } \\
\text { Berdasarkan } \\
\text { Visi Misi } \\
\text { Bupati }\end{array}$ \\
\hline 1 & \multicolumn{2}{|c|}{$\begin{array}{l}\text { Program pelayanan kesehatan peserta } \\
\text { jaminan kesehatan nasional (Dinkes) }\end{array}$} & $16.68 \%$ & 1 \\
\hline 2 & \multicolumn{2}{|c|}{$\begin{array}{l}\text { Program pelayanan kesehatan penduduk } \\
\text { miskin (Dinkes) }\end{array}$} & $29.17 \%$ & 2 \\
\hline 3 & \multicolumn{2}{|c|}{$\begin{array}{l}\text { Program peningkatan pelayanan publik } \\
\text { (Dinkes) }\end{array}$} & $15.88 \%$ & 3 \\
\hline \multirow[t]{2}{*}{4} & \multicolumn{2}{|c|}{ Program pengadaan, peningkatan dan } & & \\
\hline & \multicolumn{2}{|c|}{$\begin{array}{l}\text { perbaikan sarana dan prasarana } \\
\text { puskesmas/puskesmas pembantu dan j } \\
\text { (Dinkes)* }\end{array}$} & $0.91 \%$ & 4 \\
\hline 5 & \multicolumn{2}{|c|}{$\begin{array}{l}\text { Program standarisasi pelayanan kesehatan } \\
\text { (Dinkes) }\end{array}$} & $0.31 \%$ & 5 \\
\hline 6 & \multicolumn{2}{|c|}{$\begin{array}{l}\text { Program perbaikan gizi masyarakat } \\
\text { (Dinkes) }\end{array}$} & $1.76 \%$ & 6 \\
\hline 7 & \multicolumn{2}{|c|}{ Program pengembangan lingkungan sehat } & 0.58 & 7 \\
\hline 8 & \multicolumn{2}{|c|}{$\begin{array}{l}\text { Program promosi kesehatan dan } \\
\text { pemberdayaan masyarakat }\end{array}$} & $1.36 \%$ & 8 \\
\hline 9 & \multicolumn{2}{|c|}{$\begin{array}{l}\text { Program pencegahan dan penanggulangan } \\
\text { penyakit menular }\end{array}$} & 2.02 & 9 \\
\hline
\end{tabular}


Keterangan :

*) Anggaran hanya terdapat di tahun 2013

${ }^{* *}$ ) Anggaran hanya terdapat di tahun 2014

Berdasarkan table analisa di atas, diketahui bahwa secara keseluruhan anggaran bidang kesehatan memiliki proporsi 24.55\% untuk tahun 2013 dan $30.00 \%$ di tahun 2014. Proporsi tersebut terdiri atas anggaran Dinas kesehatan, RSUD Dolopo dan RSUD Caruban. Sehingga secara umum, anggaran bidang pendidikan telah melampaui amanah pemerintah dimana anggaran bidang kesehatan minimal $10 \%$.

Sedangkan program di bidang kesehatan yang diilustrasikan oleh Dinas Kesehatan memiliki sebaran anggaran dimana Program Pelayanan Kesehatan Penduduk Miskin paling tinggi dalam hal pembiayaan $(29.17 \%)$ namun menempati posisi kedua berdasarkan ranking berdasarkan visi misi Bupati.

\section{Bidang Pendidikan}

Analisa anggaran di Bidang Pendidikan sebagaimana disajikan dalam table di bawah ini.

Tabel 11

Analisa Program Strategis Dinas Pendidikan

\begin{tabular}{|c|c|c|c|}
\hline \multicolumn{2}{|r|}{ Dinas/kantor/ Unit } & $\begin{array}{c}\text { Proporsi Anggaran } \\
2013\end{array}$ & $\begin{array}{c}\text { Proporsi Anggaran } \\
2014\end{array}$ \\
\hline \multicolumn{2}{|c|}{ Dinas Pendidikan } & $20.20 \%$ & $2.70 \%$ \\
\hline No. & Program & $\begin{array}{c}\text { Prosentase } \\
\text { Anggaran Program } \\
\text { di SKPD }\end{array}$ & $\begin{array}{c}\text { Ranking } \\
\text { Program } \\
\text { Berdasarkan } \\
\text { Visi Misi } \\
\text { Bupati } \\
\end{array}$ \\
\hline 1 & $\begin{array}{l}\text { Program wajib belajar pendidikan } \\
\text { dasar sembilan tahun }\end{array}$ & $64.65 \%$ & 1 \\
\hline 2 & Program pendidikan menengah & $20.09 \%$ & 2 \\
\hline 3 & Program pendidikan non formal & $2.14 \%$ & 3 \\
\hline 4 & Program pendidikan luar biasa & $0.03 \%$ & 4 \\
\hline 5 & $\begin{array}{l}\text { Program peningkatan mutu } \\
\text { pendidik dan tenaga kependidikan }\end{array}$ & $1.70 \%$ & 5 \\
\hline 6 & $\begin{array}{l}\text { Program pengembangan nilai } \\
\text { budaya }\end{array}$ & $1.83 \%$ & 6 \\
\hline 7 & $\begin{array}{l}\text { Program manajemen pelayanan } \\
\text { pendidikan }\end{array}$ & $7.05 \%$ & 7 \\
\hline
\end{tabular}

Berdasarkan data analisa table di atas, diketahui bahwa anggaran bidang pendidikan tahun 2013 sebesar $20.20 \%$, dan mengalami penurunan pada tahun 2014 sebesar $12.70 \%$. Sehingga secara normative rata-rata anggaran pendidikan diluar belanja pegawai tahun 2013 dan 2014 masih dibawah kebijakan pemerintah minimal $20 \%$. Sedangkan pembiayaan prioritas terhadap 7 program terpilih secara umum menunjukkan bahwa alokasi anggaran tertinggi dan seterusnya juga konsisten dengan urutan prioritas program sesuai visi misi Bupati (RPJMD). 


\section{PENUTUP}

Kesimpulan yang dapat ditarik dari hasil analisis yang kemudian dielaborasi dengan hasil Focus Group Disscussion (FGD) dengan beberapa instansi terkait tentang kebijakan penganggaran program di kabupaten Madiun adalah sebagai berikut ;

1. Pola pengelolaan belanja daerah dan pembiayaan program-program strategis di kabupaten Madiun tahun 2013 dan tahun 2014 yaitu;

a. Anggaran Bidang Kesehatan memiliki proporsi $24.55 \%$ untuk tahun 2013 dan $30.00 \%$ di tahun 2014. Proporsi tersebut terdiri atas anggaran Dinas kesehatan, RSUD Dolopo dan RSUD Caruban. Sehingga secara umum, anggaran bidang pendidikan telah melampaui amanah pemerintah dimana anggaran bidang kesehatan minimal $10 \%$. Sedangkan program di bidang kesehatan yang diilustrasikan oleh Dinas Kesehatan memiliki sebaran anggaran dimana Program Pelayanan Kesehatan Penduduk Miskin paling tinggi dalam hal pembiayaan $(29.17 \%)$ namun menempati posisi kedua berdasarkan ranking berdasarkan visi misi Bupati.

b. Anggaran Bidang Pendidikan tahun 2013 sebesar $20.20 \%$, dan mengalami penurunan pada tahun 2014 sebesar $12.70 \%$. Sehingga secara normative rata-rata anggaran pendidikan diluar belanja pegawai tahun 2013 dan 2014 masih dibawah kebijakan pemerintah minimal $20 \%$. Sedangkan pembiayaan prioritas terhadap 7 program terpilih secara umum menunjukkan bahwa alokasi anggaran tertinggi dan seterusnya juga konsisten dengan urutan prioritas program sesuai visi misi Bupati (RPJMD).

2. Faktor penghambat dalam aspek pembiayaan program-program strategis di Kabupaten Madiun antara lain sebagai berikut;

a. Penyusunan KUA PPAS selalu bersamaan dengan Perubahan Anggaran Keuangan (PAK), hal ini ditentukan oleh penyesuaian dengan agenda DPRD, mendesaknya jadwal ini menyebabkan penyusunan tidak berjalan secara optimal, dan cenderung berpedoman pada anggaran tahun-tahun sebelumnya.

b. Kurang mendukungnya kesiapan SDM SKPD yang memiliki kemampuan dan kecakapan dalam perencanaan anggaran, kalaupun ada jumlahnya sangat sedikit dan waktunya tidak mewadai untuk concern terhadap perumusan anggaran secara optimal.

c. Banyak usulan SKPD yang disetujui di bawah plafond yang diusulkan, misalnya anggaran PU selama ini rata-rata diakomodasi dibawah yang diusulkan.

d. Pengalokasian anggaran di tiap SKPD selama ini merupakan hasil koordinasi di Tim TAPD yang kurang berpedoman pada besarnya kontribusi program-program prioritas SKPD dalam mendukung pencapaian Visi Misi Kepala Daerah.

3. Faktor Pendukung aspek pembiayaan program strategis adalah adanya beberapa SKPD yang memiliki kepemimpinan yang kuat, sehingga mampu mengerakkan segenap sumber daya SKPD untuk membuat perencanaan keuangan secara baik dan sesuai dengan tupoksi SKPD-nya.

4. Rekomendasi model pengalokasian pembiayaaan program-program strategis dengan berpijak pada satu metode tertentu yang bersifat merit system. Artinya dirumuskan sebuah formula dimana besaran alokasi belanja 
atau pembiaayaan disesuaikan dengan kontribusi masing-masing progam di setiap SKPD terhadap pencapaian visi-misi Kepala Daerah. Kemudian setiap program disepakati bersama pada Forum SKPD besar nilai koefisien/idenksnya yang mencerminkan kontribusi terhadap pencapaian visi Misi Kepala Daerah sebagaimana tertian dalam RPJMD.

\section{DAFTAR PUSTAKA}

Anggarini, Yunita. 2010. Anggaran Berbasis kinerja. Yogyakarta: STIM YKPN.

Bungin, M Burhan. 2009. Penelitian Kualitatif. Jakarta: Kencana Prenada Media group.

Dajan, Anto. 1996. Pengantar Metode Statistik Jilid II. Jakarta: Pustaka LP3ES Indonesia.

Dajan, Anto. 2001. Pengantar Metode Statistik Jilid I. Jakarta: Pustaka LP3ES Indonesia.

Halim, Abdul. 2012. Pengelolaan Keuangan Daerah. Yogyakarta: STIM YKPN.

Hyman, David N. 1999. Public Finance, A Contemporary Application of Theory to Policy. Ney York: The Dryden Press.

Lee, Robert D. 1998. Public Budgeting Systems. Maryland: Aspen Publidher Inc.

Rustiadi, Ernan, dkk. 2011. Perencanaan dan Pengembangan Wilayah. Jakarta: Crestpent Press dan Yayasan Pustaka Obor Indonesia.

Suparmoko. 2000. Keuangan Negara, dalam teori dan praktek. Yogyakarya: PT. BPFE.

The Partnership for Governance Reform, 2012. Indonesia Governance Index 2012. Jakarta: Rajawali Cipta Sentosa. 